\title{
CINEGEO
}

International Journal of Environment and Geoinformatics (IJEGEO) is an international, multidisciplinary, peer reviewed, open access journal.

\section{Shoreline evolution of Valencia Lake and land use and land cover changes in Zamora municipality, Aragua state, Venezuela, period 1986-2016.}

\author{
Abraham COIMAN \\ Chief in Editor \\ Prof. Dr. Cem Gazioğlu
}

\section{Co-Editors}

Prof. Dr. Dursun Zafer Şeker, Prof. Dr. Şinasi Kaya,

Prof. Dr. Ayşegül Tanık and Assist. Prof. Dr. Volkan Demir

Editorial Committee (December 2020)

Assos. Prof. Dr. Abdullah Aksu (TR), Assit. Prof. Dr. Uğur Algancı (TR), Prof. Dr. Bedri Alpar (TR), Prof. Dr. Levent Bat (TR), Prof. Dr. Paul Bates (UK), İrşad Bayırhan (TR), Prof. Dr. Bülent Bayram (TR), Prof. Dr. Luis M. Botana (ES), Prof. Dr. Nuray Çağlar (TR), Prof. Dr. Sukanta Dash (IN), Dr. Soofia T. Elias (UK), Prof. Dr. A. Evren Erginal (TR), Assoc. Prof. Dr. Cüneyt Erenoğlu (TR), Dr. Dieter Fritsch (DE), Prof. Dr. Çiğdem Göksel (TR), Prof.Dr. Lena Halounova (CZ), Prof. Dr. Manik Kalubarme (IN), Dr. Hakan Kaya (TR), Assist. Prof. Dr. Serkan Kükrer (TR), Assoc. Prof. Dr. Maged Marghany (MY), Prof. Dr. Michael Meadows (ZA), Prof. Dr. Nebiye Musaoğlu (TR), Prof. Dr. Masafumi Nakagawa (JP), Prof. Dr. Hasan Özdemir (TR), Prof. Dr. Chryssy Potsiou (GR), Prof. Dr. Erol Sarı (TR), Prof. Dr. Maria Paradiso (IT), Prof. Dr. Petros Patias (GR), Prof. Dr. Elif Sertel (TR), Prof. Dr. Nüket Sivri (TR), Prof. Dr. Füsun Balık Şanlı (TR), Prof. Dr. Uğur Şanlı (TR), Duygu Ülker (TR), Prof. Dr. Seyfettin Taş (TR), Assoc. Prof. Dr. Ömer Suat Taşkın (US), Assist. Prof. Dr. Tuba Ünsal (US), Dr. İnese Varna (LV), Dr. Petra Visser (NL), Prof. Dr. Selma Ünlü (TR), Prof. Dr. Murat Yakar (TR), Assit. Prof. Dr. Sibel Zeki (TR)

Abstracting and Indexing: TR DIZIN, DOAJ, Index Copernicus, OAJI, Scientific Indexing Services, International Scientific Indexing, Journal Factor, Google Scholar, Ulrich's Periodicals Directory, WorldCat, DRJI, ResearchBib, SOBIAD 


\title{
Shoreline evolution of Valencia Lake and land use and land cover changes in Zamora municipality, Aragua state, Venezuela, period 1986-2016.
}

\author{
Abraham Coiman \\ Independent researcher, Turmero 0211, Aragua, Venezuela.
}

E-mail: abrahamcoiman@gmail.com

Received 09 May 2020

Accepted 22 Sept. 2020

How to cite: Coiman, (2020). Shoreline evolution of Valencia Lake and land use and land cover changes in Zamora municipality, Aragua state, Venezuela, period 1986-2016.. International Journal of Environment and Geoinformatics (IJEGEO), 7(3): 305-318. DOI:10.30897/ ijegeo. 734872

\begin{abstract}
Understanding the current and past state of land use and land cover (LULC) changes in a region is possible through multitemporal remote sensing studies in order to identify patterns of long-term changes. This study was conducted to evaluate the shoreline dynamics of the Valencia lake and the magnitude of LULC changes in Zamora Municipality, Venezuela from 1986 to 2016. Landsat (5/7/8) images were processed and classified through the object-based approach. The image classification assessment was performed through the stratified random sampling and the unbiased accuracy assessment methods over 397 sampling units. We used GIS (Geographical Information System) analysis to estimate the magnitude of LULC changes, ascertain the evolution of the shoreline, and identify areas in conflict with the potential for agricultural use. Our image classification accuracy was $69 \%$. We found that scrublands and farmlands experienced reductions, 13029 ha, and 818 ha respectively, whereas forest, built-up, and water bodies showed increments, 11792 ha, 1482 ha, and 634 ha correspondingly. The lake shoreline underwent more than $50 \%$ of its raising during the last two study years (2003-2016). It was also observed during these two years that LULC changes prompted conflicts with other land uses, $82 \%$ of the lands affected by the shoreline increment were farmlands with high potential for crop yields, and built-up areas grew at a rate of $81 \mathrm{ha} / \mathrm{yr}$. wherein more than one third were lands with high or moderate potential for agricultural use. Our results show that scrublands and/or grasslands experienced important reductions and to a lesser degree farmlands. On the other hand, other classes experienced remarkable increments: forest, and built-up. An upward trend of the Valencia lake shoreline was determined. Further studies are advisable to determine whether the object-based or the pixel-based classification is more suitable to evaluate LULC changes in our study area.
\end{abstract}

Keywords: Land Use/ Cover, Multitemporal Remote Sensing, Object-Based Classification, Valencia Lake, Venezuela.

\section{Introduction}

The Valencia lake basin spans $3055 \mathrm{~km} 2$ and is located between the Serranía del Litoral (littoral mountains) and the Serranía del Interior (inland mountains) of the Cordillera de la Costa (coastal mountain range) in the central region of Venezuela. This basin is an endorheic basin that retains water and without outflow to other water bodies like rivers or oceans (Wikipedia, 2017). Approximately $0.3 \%$ of the territory in Venezuela is occupied by this basin, but nearly $10 \%$ of the population and $30 \%$ of the industrial infrastructure in Venezuela lie within the Valencia lake basin (Fundacite, 1999). The compulsive establishment of manufacturing and raw material processing companies in this basin has been accompanied by a significant urban sprawl.

The abovementioned issues have created enormous environmental pressures in this basin, especially since the industrialization of areas surrounding the Valencia Lake. As a result, urban centers have been expanded without planning; generating significate land use and land cover (LULC) changes. It is important to highlight that the volume of wastewater flowing into the Valencia lake has increased as a consequence of an improvised occupation of the basin's territory, especially in flatlands. For more than fifty years, this wastewater has been discharged into the lake without appropriate treatment and management (Jaimes, 2011). Therefore, the lake water is polluted and is not suitable for human consumption and recreational or agricultural activities because the lacustrine ecosystem is seriously affected by urban and industrial effluents. Since the mid-twentieth century, this basin has experienced quick population growth, generating scarcity of freshwater. To solve this problem, water from the Pao river (a tributary of the Orinoco river basin) began to be transferred since the late 1970s. In consequence, since the 1980s, the lake level has grown significantly and agricultural and urban areas have been flooded.

In this respect, areas for agricultural use in this basin have dropped due to increments of the lake level and urban and industrial areas (Fundacite, 1999). Between 1982 and 2000, urban areas grew at an average annual rate of $3.3 \%$ and $70 \%$ of this increment affected lands with high potential for agricultural use (Ormeño, 2002). From 1980 to 2000 the annual average rate of area decreases for agricultural use was 790 hectares per year (Ormeño, 2002). Due to the fast development, the Valencia lake basin has undergone, LULC changes have shown dynamic and heterogeneous behavior. Natural covers and urban and agricultural uses have experienced significant changes (Tejada, 2006).

LULC is a topic that is widely discussed and studied by several scientific disciplines. This is mainly due to the fact that unplanned human activities such as illegal logging and burning of forests, mining, agriculture, and 
urban expansion, are causing negative effects on the environment (Pontes, 2013; Burak et al., 2004).

Land cover refers to all biotic and abiotic factors of Earth's surface and the underlying subsoil. Land cover change is the conversion from one category to another, implying changes in its condition, for example, changes from agriculture to urban areas, or forest degradation (Giri, 2012; Kaya et al., 20017). Land use can be defined as the way by which human beings use or occupy the territory. This term is related to socioeconomic factors that influence a particular use of the territory (e.g. production, recreation, conservation, etc.). Land use change refers to the substitution of one use for another one due to human activities, for example, a forest can be used as a protected area (e.g. change of use), resulting in a greater number of visitors, which does not imply a change in land cover (Giri, 2012; Gazioğlu et al., 1997; Islam et al.,I 2016; Mohammadı and Hosseinal1, 2019).

LULC changes are caused directly or indirectly by human activities seeking to ensure essential resources. This may have happened for the first time when humans burned vegetation in order to facilitate hunting. Agricultural activities have accelerated this process dramatically, resulting in widespread deforestation and intervention of the Earth's surface. Recently, the industrialization has triggered population growth in urban areas and population depletion in rural areas. This has intensified the use of the most productive lands for agriculture and the marginalization of the less suitable lands (The Encyclopedia of Earth 2010).

Data captured through remote sensing techniques and their analyses provide detailed information for monitoring LULC changes (Rogan and DongMe, 2004). The accessibility of free and low-cost data generated from remote sensing and new image analysis techniques have encouraged the remote-sensing community to generate information for LULC mapping (Mallinis and Georgiadis, 2019). In contrast to traditional methods, LULC mapping using remotely sensed data is faster and cheaper, map products are readily updated. It is straightforward to join remotely sensed data with data derived from GIS, and by using data obtained from remote sensing it is possible to map large areas (Toure, et al., 2018), which is very useful for LULC purposes.

There are a variety of remote sensing techniques producing various results due to the remotely sensed data, environmental conditions, and image processing methods (Berberoglu and Akin, 2009). Mapping accurately land use and land cover using remote sensing techniques requires adequate image classification methods (Ngan Lam, 2008). Image classification is an essential stage during the image analysis that allows users to group pixels of an image into classes or categories representing land covers (Patil, et al., 2012).
New classification methods have been devised to enhance the classification process (Ngan Lam, 2008). New methods such as fuzzy classification, artificial neural network, and object-based classification have been successfully applied (Ngan Lam, 2008). The object-based classification uses the sizes, shapes, textures and spectral features of the regions (Campbell and Wynne, 2011). To extract features, the object-based paradigm makes use of all aspects of remote sensing, especially spectral, spatial, contextual, textural and temporal properties of the features (Navulur, 2007).

The purpose of this work is to evaluate the shoreline dynamic of the Valencia Lake and its LULC changes through geomatics tools, focusing on the Zamora municipality in the Aragua state. These dynamic and LULC changes were assessed by classifying medium resolution satellite imagery using the object-based approach between 1986 and 2016.

The main objective of this work is to evaluate the evolution of the Valencia lake shoreline and LULC changes in Zamora municipality Aragua state from 1986 to 2016. Other objectives are as follows: (i) describe LULC changes in Zamora municipality between 1986 and 2016; (ii) ascertain the evolution of the lake shoreline in the study area from 1986 to 2016; (iii) identify areas in conflict with the potential agricultural land use in the study area between 1986 and 2016.

\section{Study Area}

Zamora municipality is located at the middle part of the Aragua state (Figure 1). Its limits are the following: North: Libertador, José Ángel Lamas and Sucre municipalities; South: Guárico state; East: San Sebastián and José Félix Ribas municipalities; West: Carabobo state (Figure 2).

Zamora municipality is in the Aragua state in Venezuela and spans an area of 68424 hectares. The western portion of this municipality lies in the Valencia lake basin where important urban centers are located: Villa de Cura (capital city), Tocorón and San Francisco de Asís. On the other hand, the eastern area of this municipality that makes up the Guárico river basin is predominantly hilly and has not urban development. This work is based on the LULC changes that occurred in this territory.

Almost all the Zamora municipality territory has a tropical savanna climate. The predominant vegetation is savanna, with some features of premontane forests. The most important economic activities of this municipality are mining, agriculture, and industries. Its relief is formed by the Serranía del Interior (inland mountains), which in geological terms is a recent mountainous block. Open or natural paths such as Villa de Cura allow the communication between the Valencia lake basin, the Aragua valleys and the Guariqueños Plains (Wikipedia, 2016). 


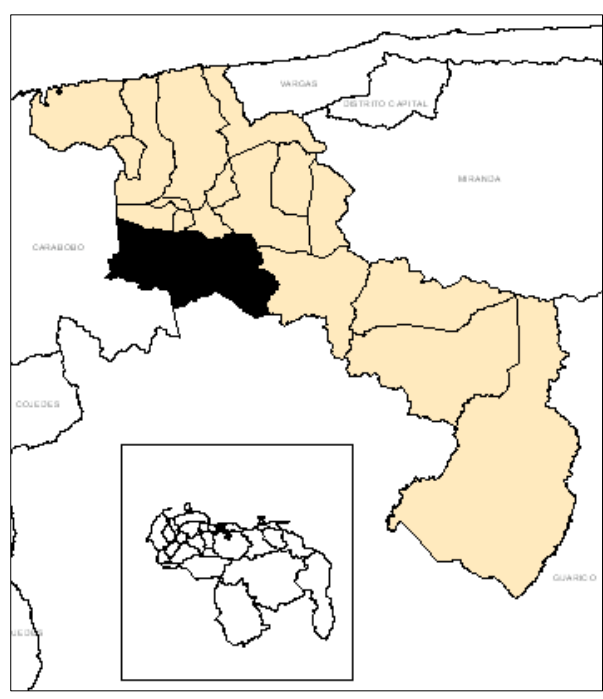

Figure 1. Study Area

\section{Materials and Methods Datasets}

Cartographic information was reviewed in order to obtain geospatial data and information related to the study area. In this regard, vector and raster datasets of the Aragua state administrative areas, land use classifications, topography, among others, were selected and used. These datasets were mainly obtained from the Ministry of Environment, the Faculty of Agronomy UCV (Universidad Central de Venezuela) and the regional government.

Landsat 5, 7 and 8 images were obtained from the Geological Survey of the United States (USGS) through the website http://earthexplorer.usgs.gov/. Landsat 5 and 7 thermal infrared band (band 6), and Landsat 8 coastal aerosol (band 1), cirrus (band 9), and infrared thermal bands (band 10,11) were not taken into account since they are generally used for coastal and aerosol studies, cirrus cloud contaminations and soil moisture (USGS, Table 1. Images used in this study

\begin{tabular}{cccc}
\hline Study Period & Acquisition / Study Year & Mission/Sensor & Processed Bands \\
\hline \multirow{2}{*}{$1986-1998$} & 1986 & Landsat 5 (TM) & $1-6$ \\
$1998-2003$ & 1998 & Landsat 5 (TM) & $1-6$ \\
$2003-2016$ & 2003 & Landsat 7 (ETM+) & $1,2,3,4,5,7$ \\
\hline
\end{tabular}

Table 2. CORINE Land Cover Colombia legend adapted to this study

\begin{tabular}{ll}
\hline \multicolumn{1}{c}{ Level 1 } & \multicolumn{1}{c}{ Level 2 } \\
\hline 1. Artificial Surfaces & 1.1 Urban fabric \\
& 1.2 Industrial and commercial units \\
& 1.3 Mine and dump sites \\
2. Agricultural Areas & 2.1 Heterogeneous agricultural areas \\
3. Forest and Semi Natural Areas & 3.1 Forests \\
& 3.2 Scrub and/or herbaceous vegetation associations \\
4. Water Bodies & 3.3 Open spaces with little or no vegetation \\
\hline
\end{tabular}




\section{Image Pre-processing}

In the image processing step, three operations were performed on each of the selected images: cropping, atmospheric correction, and enhancements. It is important to highlight that when multitemporal studies are carried out, it is necessary to atmospherically correct the images since the scattering is not the same for images acquired on different dates (Chuvieco, 1995; Kaya et al., 2015).

The FLAASH module (Fast Line-of-sight Atmospheric Analysis of Spectral Hypercubes) of the ENVI 5.1 software was used for image atmospheric correction. The eCognition Developer software was used for image enhancement. Images used in this study were not geometrically corrected because the USGS performs a standard terrain correction (level 1T) with systematic radiometric and geometric accuracy (Rodríguez, 2011).

\section{Image Classification}

Landsat image classification was carried out by using the eCognition Developer 8.0 and the object-based approach. The following steps were executed in order to perform the object-based classification (Figure 3). (i) loading land use vectors and image composites into eCognition projects; (ii) definition of parameters used by the Multiresolution Segmentation algorithm; (iii) building class trees from the categories shown in Table 2; (iv) collecting training samples to define parameters of the classification rules. Ten (10) samples were collected per category since each of them must be made up by a number of training sites (at least 5 to 10) that ensure that their spectral properties are represented (Campbell and Wynne 2011); (v) definition of classification rules for each coverage classes based on the membership function classifier. The membership function method uses the fuzzy logic approach to classify image objects (Xiaoxiaa, et al., 2004); The classification rules were based on image composites and vegetation indices like Normalized Difference Vegetation Index (NDVI), Ratio Vegetation Index (RVI), Soil-adjusted Vegetation Index (SAVI), and Difference Vegetation Index (DVI). The classification rule for the Inland waters class was defined from the Land Water Mask (LWM) used by (ICIMOD, 2015); (vi) defining algorithms to classify objects based on classification rules and vector layers. The following algorithms were used: Classification, Assign Classes by Thematic Layer and Assign Class; (vii) image classification assessment through the error matrix (confusion matrix) based on the unbiased accuracy assessment method proposed by (Olofsson, et al., 2013). The classification assessment was only performed on six classes of the 2016 classification results due to the lack of ground truth data for all the classified images. The Copernicus Global Land Cover Layers: CGLS-LC100 collection 2 (Buchhorn, et al., 2019) and the Google Earth Engine Python API were used to capture ground truth samples. 397 random sample points were selected within the strata or classes using the stratified random sampling method and the NOAA Biogeography Branch's Sampling Design Tool for ArcGIS (NCCOS, 2017).

\section{Image post-classification}

In the post-classification phase, all the classified objects were processed in order to generate vector layers that were used in subsequent stages of spatial analysis. The objects were merged with the Merge Region algorithm of eCognition and then exported as shapefile layers. Vector layers were adapted to the minimum mapping unit (MMU) that was set at 25 ha which is equivalent to $1 / 4 \mathrm{~cm} 2$ at a 1: 100000 scale. Finally, shapefile layers were reduced to the Zamora municipality extent through a cutting operation.

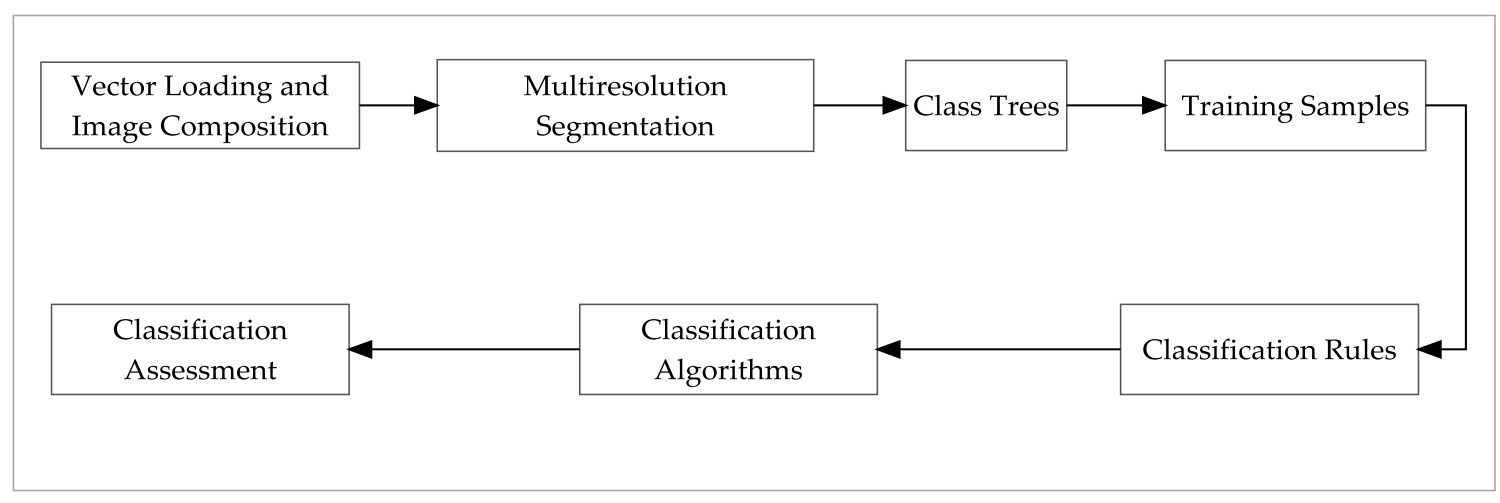

Figure 3. Steps executed to carried out the object-based classification.

\section{Evolution of the lake shoreline, and the agricultural and urban use}

To calculate the evolution of the lake shoreline, the area occupied by the lake was extracted from each study year shown in Table 1. Layers of consecutive years were joined to obtain polygons containing data about the variation of the lake surface for each period of study depicted in Table 1. This task was carried out through ArcGIS Desktop 10.1. The FID field of the resulting attributive table was used to pinpoint growth polygons of the lake. To calculate the lake shoreline level of each study year, the above-mentioned polygons were transformed into polylines from which the lacustrine shoreline was obtained. Then, a $10 \mathrm{~m}$ buffer was calculated that was used to extract the portion of the MDE-SISDELAV (Sistema de Información de Suelos de la Depresión del Lago de Valencia) and the shoreline mean elevation or each study year. 
To obtain agricultural use and urban use areas, a procedure similar to the above-mentioned was used. For each study year, areas of agricultural and urban use were selected and converted into new layers. Then, layers of consecutive study years were joined in order to obtain polygons containing the variation of the agricultural and urban areas by period of study. The FID attribute was equally used to determine areas that increased or decreased.

\section{Identification of areas in conflict with potential agricultural land use}

The identification of areas in conflict with potential agricultural land use was carried out on the following classes: Inland waters (lake), Heterogeneous agricultural areas and Urban fabric. To do that, the following layers were processed: increment of the lake area, raise and shrink of agricultural and urban use, and potential land use from SISDELAV data. QGIS 2.18 was used to clip the SISDELAV data using the corresponding increment and decrement polygon. This procedure allowed obtaining the data to quantify and characterize the potential agricultural land use affected by the evolution of the lake shoreline, the increase and/or decrease of agricultural areas and the urban expansion in Zamora municipality.

\section{Results \\ Accuracy Assessment}

As mentioned previously, the image accuracy assessment was calculated through the unbiased accuracy assessment method. The following statistics are presented: (i) confidence interval, (ii) user accuracy, (ii) producer accuracy, and (iv) overall accuracy. A confidence interval gives a range of values for a certain parameter considering the uncertainty of the examplebased estimate (Olofsson, et al., 2013); user accuracy is the probability of commission error while producer accuracy is the probability of omission error, and the proportion of the area classified correctly is the overall accuracy (Olofsson, et al., 2013). A total of 397 sampling points were used for the accuracy assessment of the year 2016, and the overall accuracy was $69 \%$. Producer accuracy for all classes ranged from $53 \%$ to 95 $\%$, the user accuracy from $47 \%$ to $84 \%$ and the error (in hectares) of the area estimate for all classes varies from 650 to 2965 (Table 3). Although accuracy assessment between 75-85 \% is acceptable (Mubako, et al., 2018), the overall accuracy is slightly below this range, that means, on average, that the chance a pixel will be correctly classified is $69 \%$. This could be attributed to the difference between the spatial resolution of the reference data $(100 \mathrm{~m})$ and the classified data $(30 \mathrm{~m})$. The latter explains why the urban and the agricultural classes showed low producer (e.g. omission error) and user (e.g. commission error) accuracy respectively, and wide confidence intervals (Table 3). Despite the limitation of available data for accuracy assessment, the reliability of the classified results is generally acceptable.

Table 3. Unbiased accuracy assessment summary table

\begin{tabular}{|c|c|c|c|c|c|}
\hline Class & $\begin{array}{c}\text { Area } \\
\text { (hectares) }\end{array}$ & $\begin{array}{c} \pm 95 \% \\
\text { CI }\end{array}$ & $\begin{array}{c}\text { User's } \\
\text { Accuracy }(\%) \\
\end{array}$ & $\begin{array}{c}\text { Producer's } \\
\text { Accuracy }(\%) \\
\end{array}$ & $\begin{array}{c}\text { Overall } \\
\text { Accuracy }(\%)\end{array}$ \\
\hline Urban fabric & 3331.13 & $\begin{array}{c}1126.8 \\
8\end{array}$ & 76.9 & 50.8 & \multirow[b]{2}{*}{69.09} \\
\hline Inland waters & 2892.68 & 649.47 & 84.2 & 93.7 & \\
\hline Forest & 22785.60 & $\begin{array}{c}2731.3 \\
0\end{array}$ & 66.7 & 65.7 & \\
\hline $\begin{array}{l}\text { Scrub and/or herbaceous } \\
\text { Vegetation associations }\end{array}$ & 34038.40 & $\begin{array}{l}2964.8 \\
5\end{array}$ & 73.7 & 68.2 & \\
\hline Heterogeneous agricultural areas & 3676.75 & $\begin{array}{c}1144.4 \\
6\end{array}$ & 47.7 & 95.6 & \\
\hline
\end{tabular}

Table 4. Area of LULC categories per year of study

\begin{tabular}{|c|c|c|c|c|c|}
\hline \multirow[b]{2}{*}{ Class/Year } & \multicolumn{5}{|c|}{ AREA (ha) } \\
\hline & 1986 & 1998 & 2003 & 2016 & $\begin{array}{c}\text { Variation } \\
1986-2016\end{array}$ \\
\hline Inland waters & 2677 & 2949 & 2917 & 3311 & 634 \\
\hline Open spaces with little or no vegetation & 522 & 2890 & 4187 & 388 & -134 \\
\hline Heterogeneous agricultural areas & 8412 & 8257 & 8454 & 7594 & -818 \\
\hline Scrub and/or herbaceous vegetation associations & 46451 & 51811 & 48861 & 33422 & -13029 \\
\hline Forest & 9387 & 1238 & 2388 & 21179 & 11792 \\
\hline Mine and dump sites & 72 & 107 & 240 & 148 & 76 \\
\hline Industrial and commercial units & 145 & 197 & 193 & 142 & -3 \\
\hline Urban fabric & 758 & 975 & 1184 & 2240 & 1482 \\
\hline TOTAL & 68424 & 68424 & 68424 & 68424 & \\
\hline
\end{tabular}



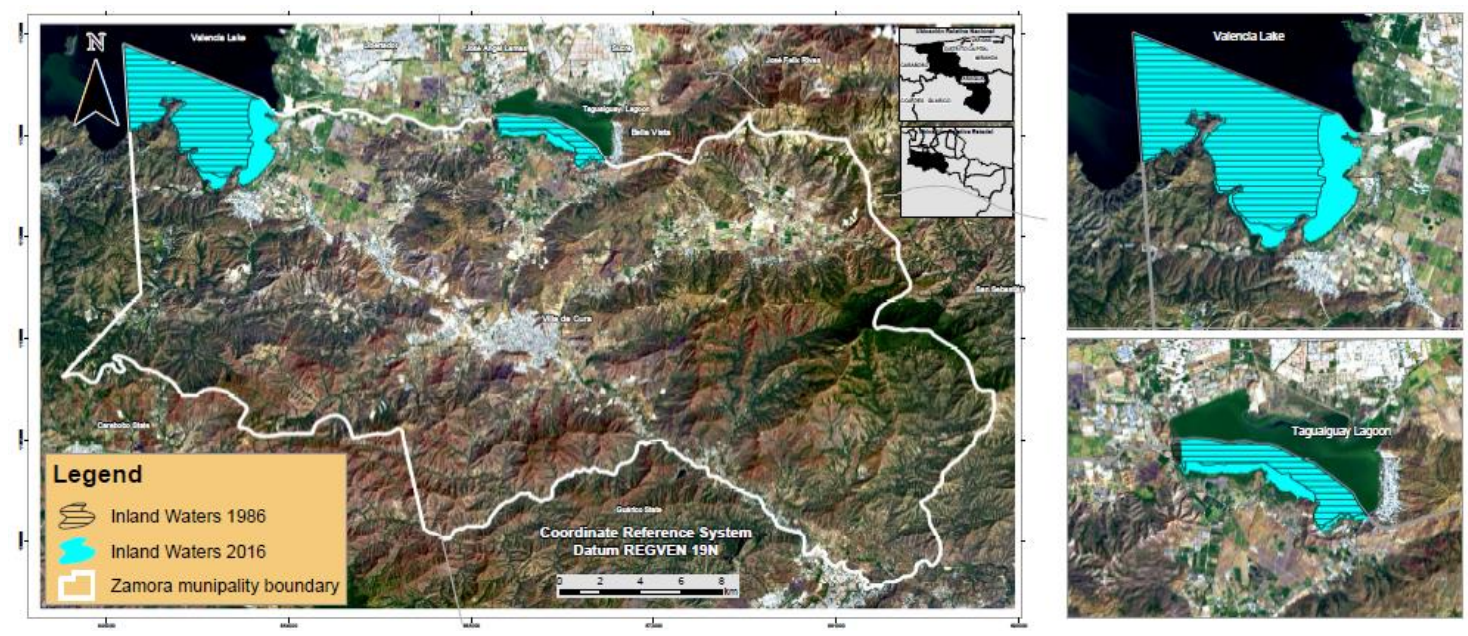

Figure 4. Variation of Inland waters in Zamora Munipality between 1986 and 2016
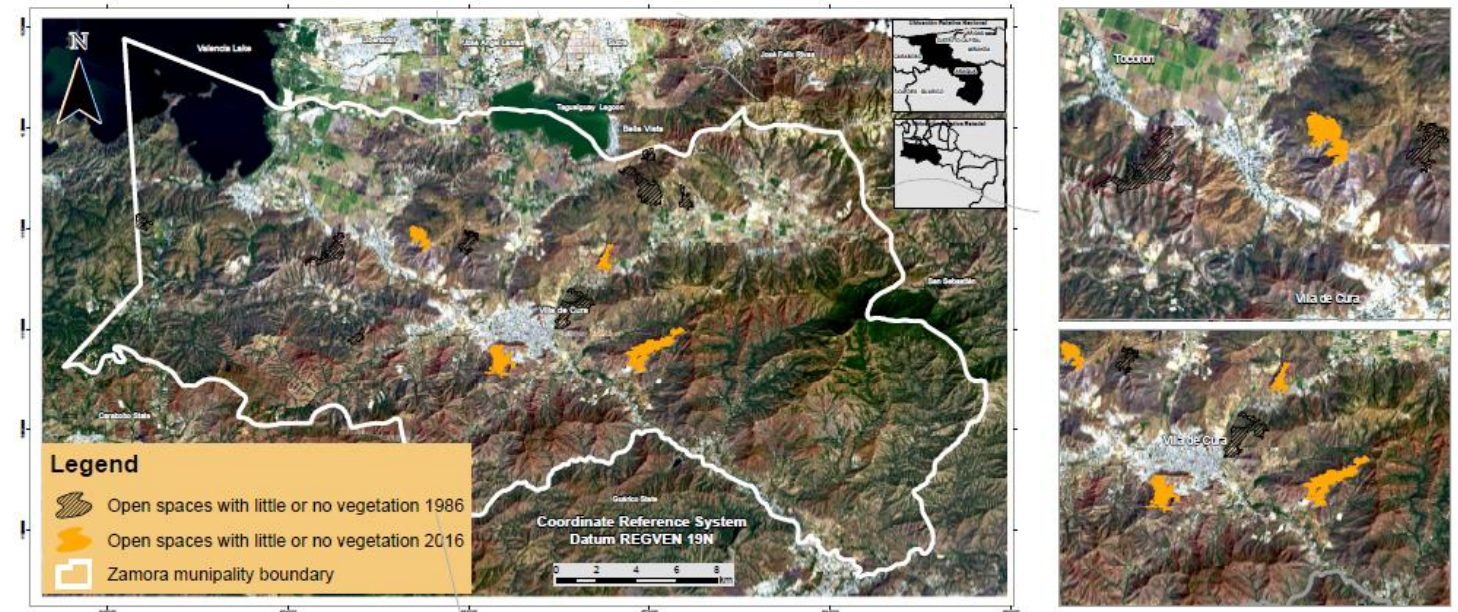

Figure 5. Variation of Open spaces with little or no vegetation in Zamora Munipality, between 1986 and 2016.
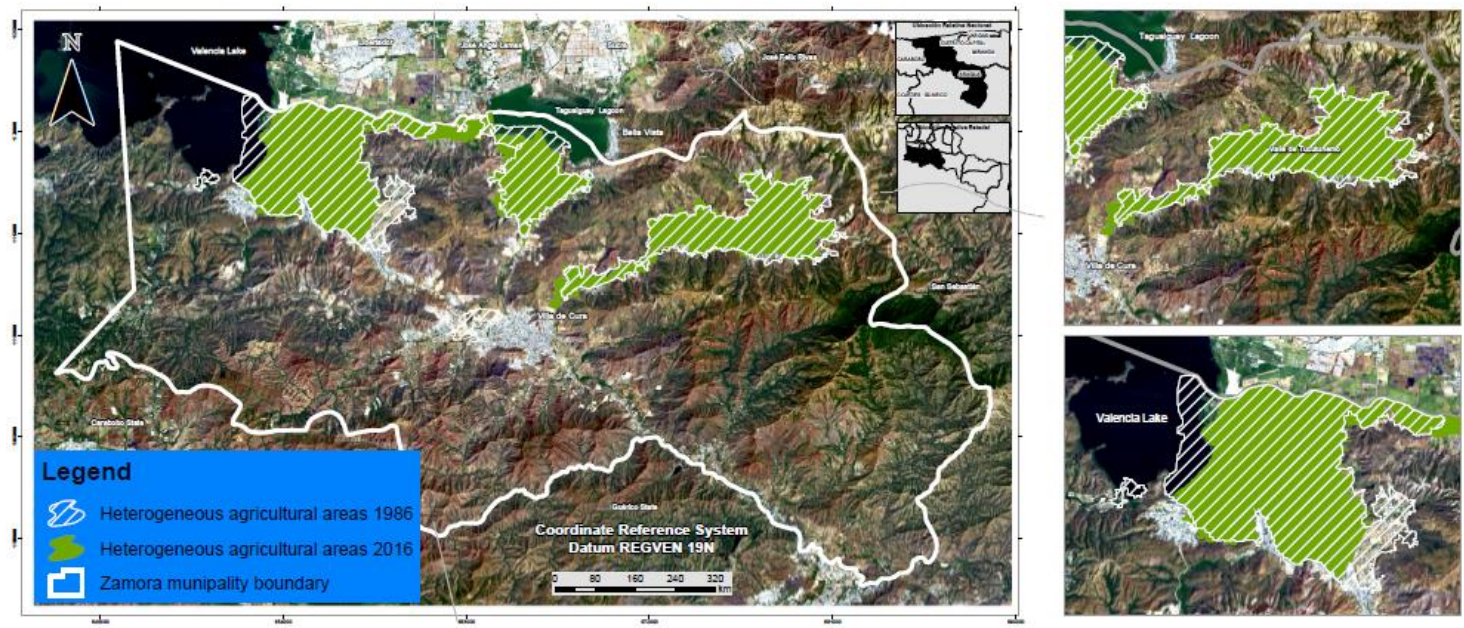

Figure 6. Variation of Heterogeneous agricultural areas in Zamora Munipality, between 1986 and 2016 

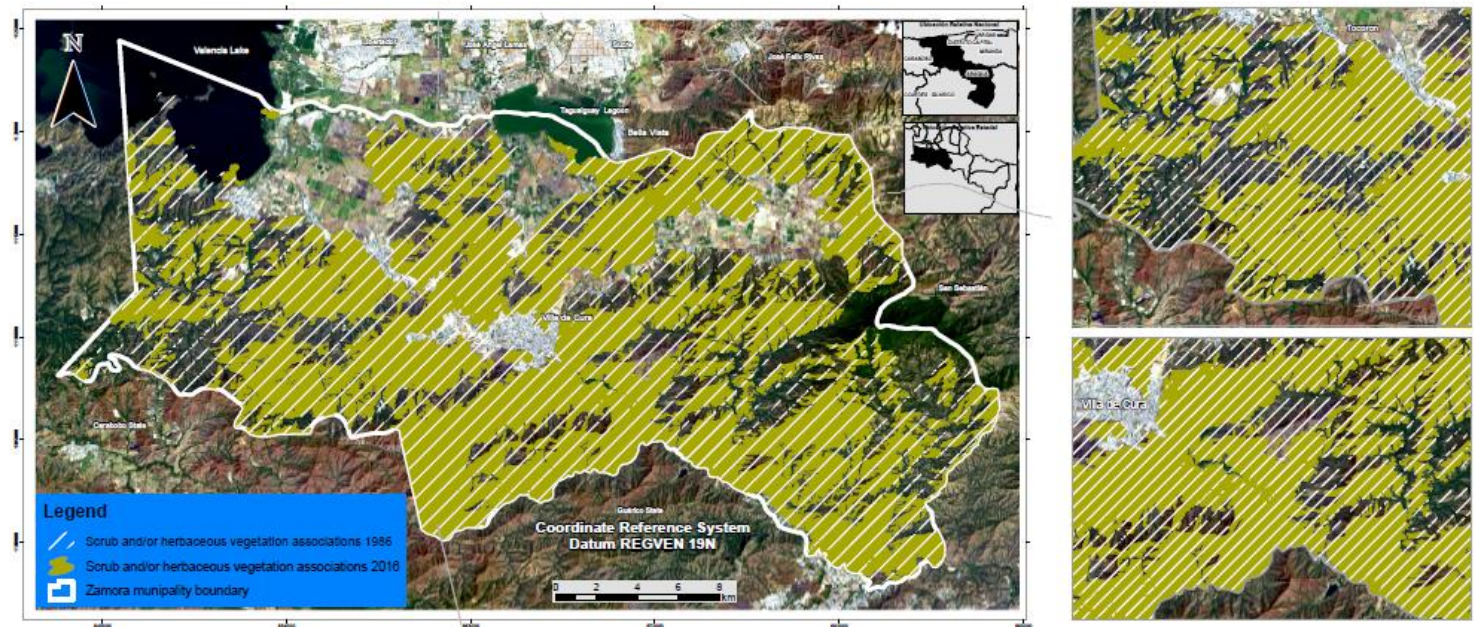

Figure 7. Variation of Scrub and/or herbaceous vegetation associations in Zamora Munipality, between 1986 and 2016
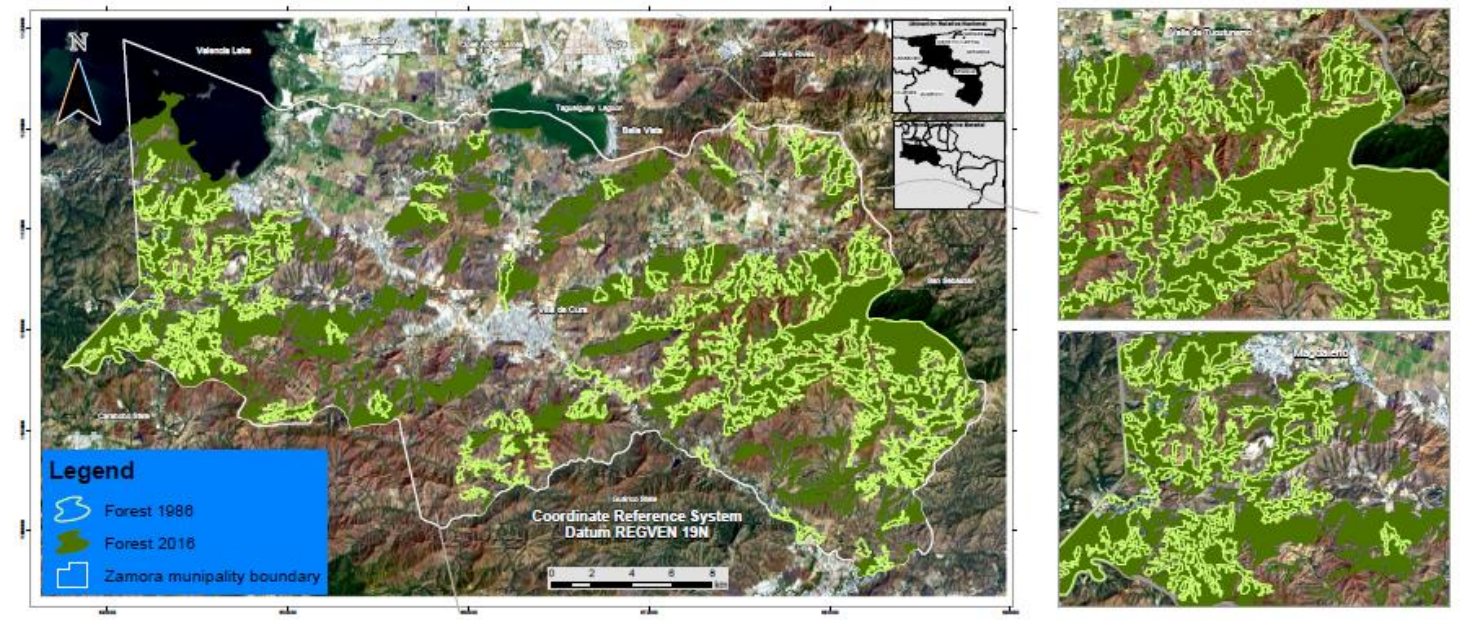

Figure 8. Variation of Forests in Zamora Munipality, between 1986 and 2016.

\section{Land Use and Land Cover Changes}

Areas of LULC classes showed a variable behavior between 1986 and 2016. Table 4 shows the area of each class for each study year. Inland waters class showed a constant increase throughout the study years, its variation between 1986 and 2016 was 634 ha (Figure 4, Table 3). The category named Open spaces with little or no vegetation showed a notable decrease in its surface between 1986 and 2016 with a variation of -134 ha (Figure 5, Table 4). The Heterogeneous agricultural areas class showed a downward trend in its surface between 1998 and 2016, the difference in the area occupied by this class between 1986 and 2016 was -818 ha (Figure 6, Table 4).

The area of Scrub and/or herbaceous vegetation associations showed a variable trend with increases between 1986 and 1998 and declines from 1998 to 2016, its variation was -13029 ha between 1986 and 2016 (Figure 7, Table 4). Forests showed a dramatic decline in more than 8000 hectares of their surface from 1986 to 2003. Between 2003 and 2016 the area occupied by this land cover experienced remarkable increases, the surface variation was 11792 ha from 1986 to 2016 (Figure 8, Table 4).

Mine and dump sites and Industrial and commercial units showed variable behaviors throughout the study years. The area of Mine and dump sites varied 76 ha between 1986 and 2016 (Figure 9, Table 4). Industrial and commercial units decreased by 3 ha in its surface during the above-mentioned period (Figure 10, Table 4). Like inland waters, the Urban fabric class showed a sustained increase in its area between 1986 and 2016, with a variation of 1482 ha (Figure 11, Table 4). 

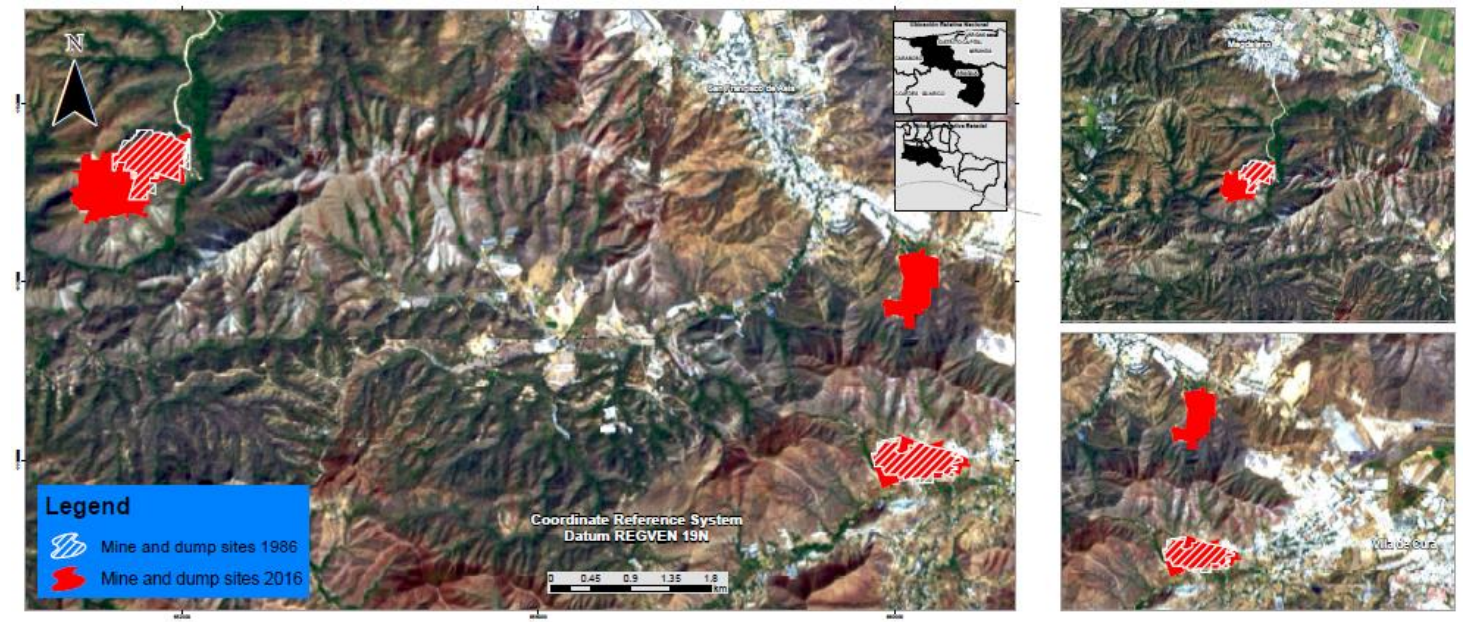

Figure 9. Variation of Mine and dump sites in Zamora Munipality, between 1986 and 2016
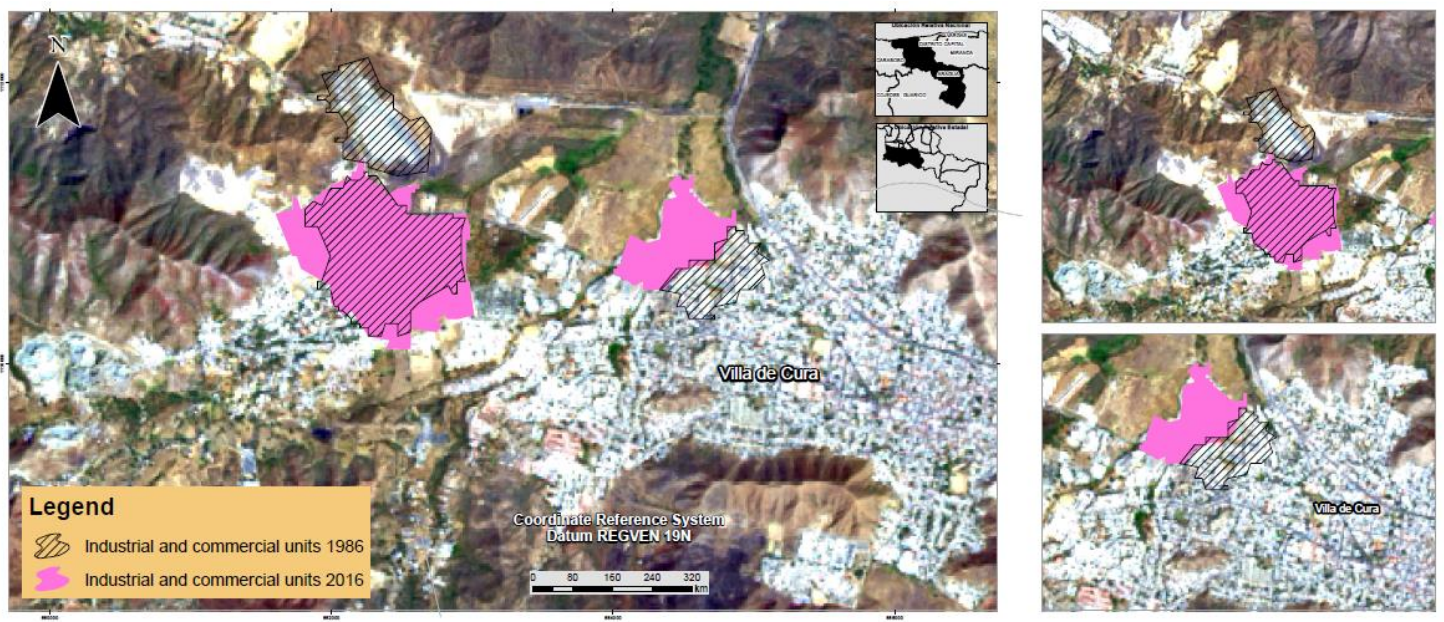

Figure 10. Variation of Industrial and commercial units in Zamora Munipality, between 1986 and 2016
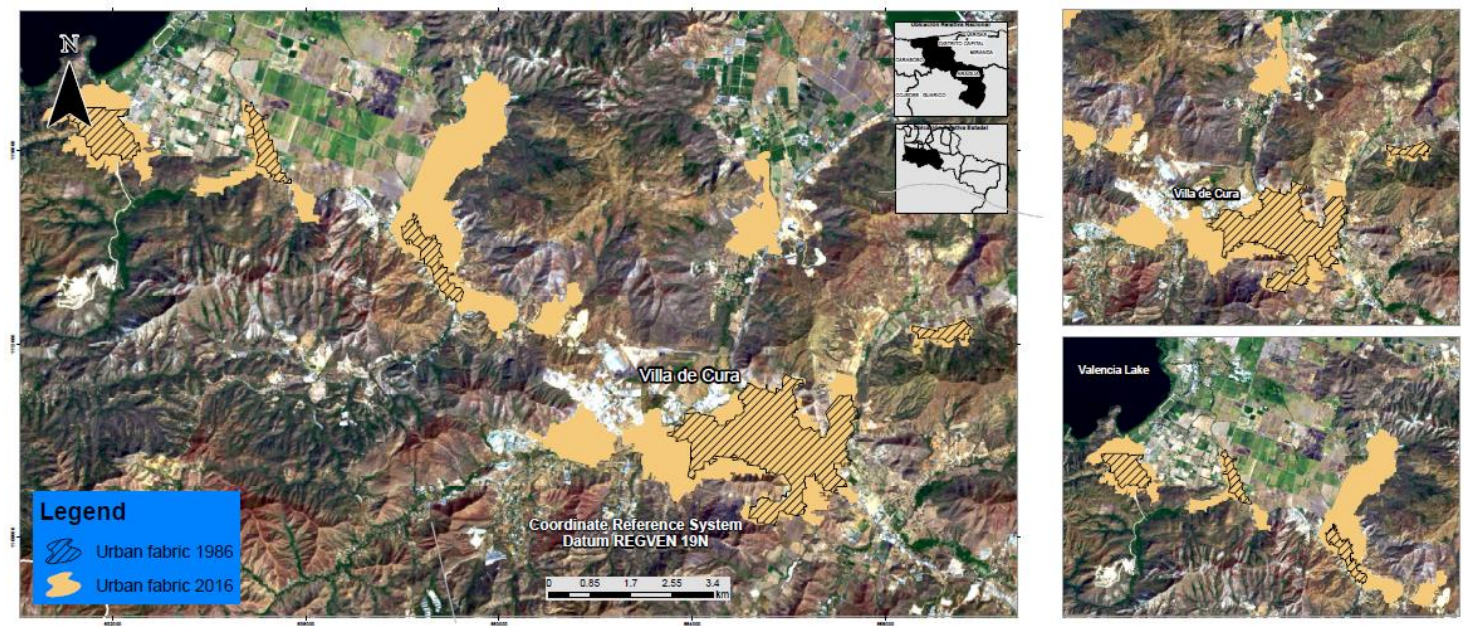

Figure 11. Variation of Urban fabric in Zamora Munipality, between 1986 and 2016

\section{Shoreline growth}

Valencia Lake expanded over an area of 544 ha between 1986 and 2016. From 1986 to 1998 the surface of the lake increased by 158 ha, this is equivalent to $29 \%$ of the total expansion between 1986 and 2016. From 1998 to 2003 the increase in the area occupied by the lake attained 66 ha, which represents $12 \%$ of the increase between 1986 and 2016. The Valencia lake increased its surface in 320 ha (59\%) between 2003 and 2016.
The shoreline level of the Valencia lake showed an upward behavior between 1986 and 2016. From 1986 to 1990, this level rose from 387 meters above sea level (masl) to 390 masl, which is equivalent to a variation of 3 m. Between 1998 and 2003 the lake level increased by $7 \mathrm{~m}$ with 397 masl for 2003. The level of the lake increased by $25 \mathrm{~m}$ between 2003 and 2016 with values of 422 masl for the last year (Figure 12). 


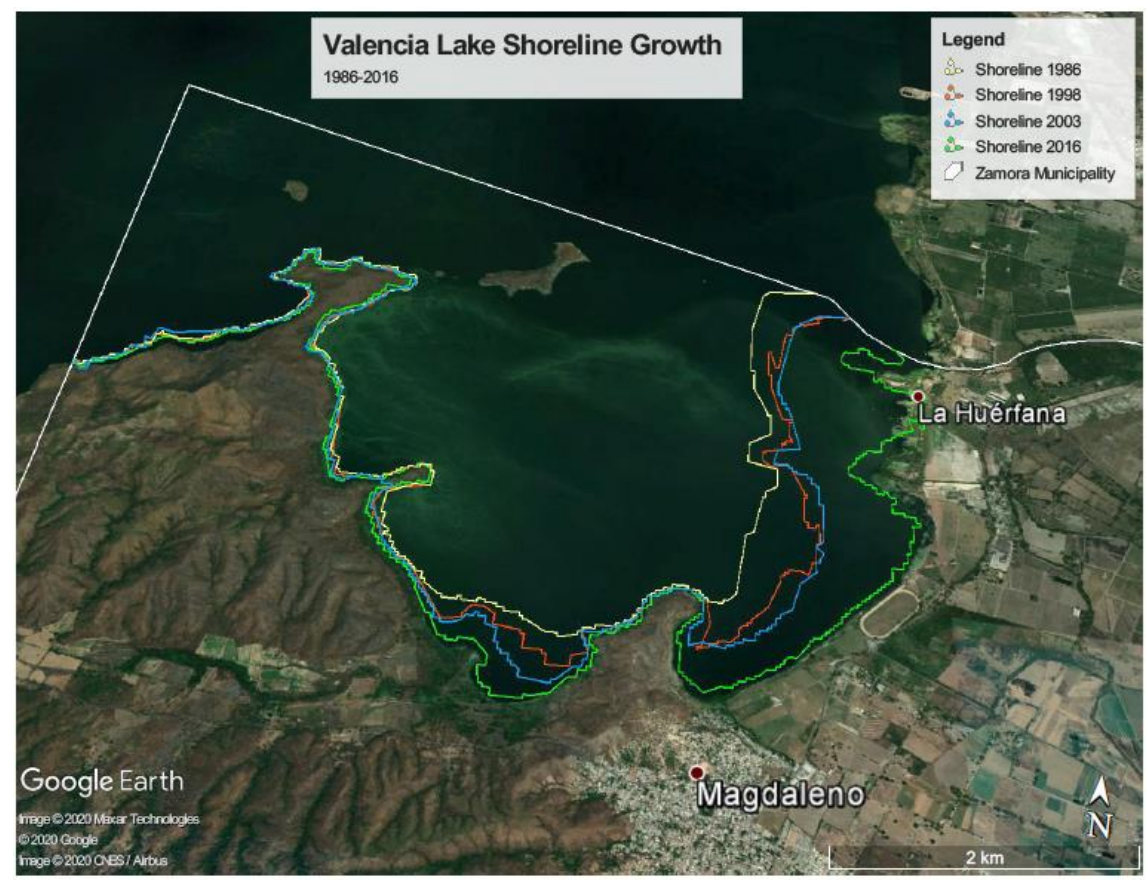

Figure 12. Shoreline growth of Valencia lake between 1986 and 2016.

Table 5. Surface variation of the Heterogeneous agricultural areas between study periods

\begin{tabular}{|c|c|c|c|c|c|c|c|c|}
\hline Period & Increase (ha) & \multicolumn{3}{|c|}{ Decrease (ha) } & \multicolumn{2}{|c|}{ Increase $(\%)$} & \multicolumn{2}{|l|}{ Decrease $(\%)$} \\
\hline 1986- 1998 & 907 & & \multicolumn{2}{|c|}{1062} & \multicolumn{2}{|c|}{46.06} & \multicolumn{2}{|c|}{53.94} \\
\hline $1998-2003$ & 1051 & & \multicolumn{2}{|c|}{854} & \multicolumn{2}{|c|}{55.17} & \multicolumn{2}{|c|}{44.83} \\
\hline $2003-2016$ & 642 & & \multicolumn{2}{|c|}{1502} & \multicolumn{2}{|c|}{29.94} & \multicolumn{2}{|c|}{70.06} \\
\hline $1986-2016$ & 2600 & & \multicolumn{2}{|c|}{3418} & \multicolumn{2}{|c|}{43.20} & \multicolumn{2}{|c|}{56.80} \\
\hline \multicolumn{9}{|c|}{ Table 6. Potential for agricultural use affected by the shoreline growth } \\
\hline & \multicolumn{8}{|c|}{ Period } \\
\hline & \multicolumn{2}{|c|}{ 1986-1998 } & \multicolumn{2}{|c|}{ 1998-2003 } & \multicolumn{2}{|c|}{ 2003-2016 } & \multicolumn{2}{|c|}{ 1986-2016 } \\
\hline $\begin{array}{l}\text { Potential for } \\
\text { agricultural use }\end{array}$ & $\begin{array}{r}\text { Area } \\
\text { (ha) } \\
\end{array}$ & $\%$ & $\begin{array}{r}\text { Area } \\
\text { (ha) }\end{array}$ & $\%$ & $\begin{array}{r}\text { Area } \\
\text { (ha) }\end{array}$ & $\%$ & $\begin{array}{r}\text { Total } \\
\text { (ha) }\end{array}$ & $\%$ \\
\hline High & 41 & 26 & 32 & 48 & 264 & 83 & 337 & 62 \\
\hline Moderate & 4 & 3 & 4 & 6 & 15 & 5 & 23 & 4 \\
\hline Low & 91 & 58 & 19 & 29 & 21 & 7 & 131 & 24 \\
\hline Very low & 1 & 1 & 1 & 2 & 6 & 2 & 8 & 1 \\
\hline No data & 21 & 13 & 10 & 15 & 14 & 4 & 45 & 8 \\
\hline Total (ha) & 158 & & 66 & & 320 & & 544 & \\
\hline \multicolumn{9}{|c|}{ Table 7. Potential for agricultural use affected by the urban growth } \\
\hline & \multicolumn{8}{|c|}{ Period } \\
\hline & \multicolumn{2}{|c|}{ 1986-1998 } & \multicolumn{2}{|c|}{ 1998-2003 } & \multicolumn{2}{|c|}{ 2003-2016 } & \multicolumn{2}{|c|}{ 1986-2016 } \\
\hline $\begin{array}{l}\text { Potential for } \\
\text { agricultural use }\end{array}$ & $\begin{array}{r}\text { Area } \\
\text { (ha) } \\
\end{array}$ & $\%$ & $\begin{array}{r}\text { Area } \\
\text { (ha) }\end{array}$ & $\%$ & $\begin{array}{r}\text { Area } \\
\text { (ha) }\end{array}$ & $\%$ & $\begin{array}{r}\text { Total } \\
\text { (ha) }\end{array}$ & $\%$ \\
\hline High & 19 & 7 & 26 & 11 & 361 & 34 & 406 & 26 \\
\hline Moderate & 13 & 5 & 14 & 6 & 36 & 3 & 63 & 4 \\
\hline Low & 36 & 13 & 22 & 9 & 75 & 7 & 133 & 8 \\
\hline Very low & 92 & 34 & 33 & 13 & 240 & 23 & 365 & 23 \\
\hline No data & 107 & 40 & $\begin{array}{r}15 \\
0 \\
\end{array}$ & 61 & 341 & 32 & 598 & 38 \\
\hline Total (ha) & 267 & & $\begin{array}{r}24 \\
5\end{array}$ & & 1053 & & 1565 & \\
\hline
\end{tabular}




\section{Evolution of the urban and agricultural land use}

Between 1986 and 2016 urban areas increased by 1482 ha. From 1986 to 1998, urban areas in the Zamora municipality increased by 217 ha, which represents $15 \%$ of the increment between 1986 and 2016. Urban areas augmented by 209 ha (14\%) between 1998 and 2003. From 2003 to 2016 occurred the greatest expansion of the urban fabric class with an increase of 1056 ha, representing $71 \%$ of the growth between 1986 and 2016 .

Between 1986 and 2016, agricultural areas showed a downward trend of its surface since the extent of decrease was greater than the extent of increase (Table 5). From 1986 and 2016 Heterogeneous agricultural areas increased by 2600 ha and decreased by 3418 ha. These figures support its tendency towards the shrinking of its surface.

\section{Areas in conflict with the potential agricultural land use}

Between 1986 and 2016 the lake shoreline expansion flooded 544 ha. $66 \%$ of the affected areas were lands with high and moderate potential for agricultural use, while $25 \%$ of the areas were lands with low to very low potential for farming activities. From 1986 to 1998 the shoreline expansion mainly flooded lands with low potential agricultural use (91 ha). Between 1998 and 2003 essentially, 32 ha with high potential for agricultural use were waterlogged, while during the period 2003-2016, 264 ha of land losses with high potential were quantified (Table 6). At the beginning the affectation was low and on soils with a high water table, then, in the period 2003-2016, the affected area was more extensive and mainly on well-drained soils, with high potential agricultural land use.
Defining areas in conflict with urban growth was based on quantifying the potential for agricultural use affected by urban development. In general, during the study period (1986-2016), lands with high potential (406 ha.) and lands with very low potential (365 ha.) for agricultural use were affected by the expansion of urban areas (Table 7). It was not possible to calculate the potential for agricultural use in $38 \%$ of the affected area because there was not SISDELAV data. In the beginning, the urban growth overlaid land with low potential for agricultural use, then when engineering limitations constrained the urbanization, lands with high potential for agricultural use were affected (period 20032016). Urban shrinking areas (83 ha) for the overall study period (1986-2016) were not included in this analysis.

Heterogeneous agricultural areas showed increases and decreases in its surface during the study period (19862016) (Figure 13). From 1986 to 2016 the increase of agricultural areas was carried out mainly on lands with low to very low potential for agricultural use (37\%), but there is only $1 \%$ of difference in comparison with the other classes of potential for agricultural use (Figure 14). There was no SISDELAV data for $27 \%$ of the areas affected by the increase of agricultural areas. Along the overall study period (1986-2016), shrinking of Heterogeneous agricultural areas was made up of land with high to moderate potential for agricultural use $(45 \%)$, and there was no SISDELAV data for $23 \%$ of the areas affected by the decrease of agricultural areas (Figure 15). Similar to (Tejada, 2006), in general, it was possible to determine that between 1986 and 2016, Heterogeneous agricultural areas showed a downward trend made up essentially of land with high to moderate potential for agricultural use.
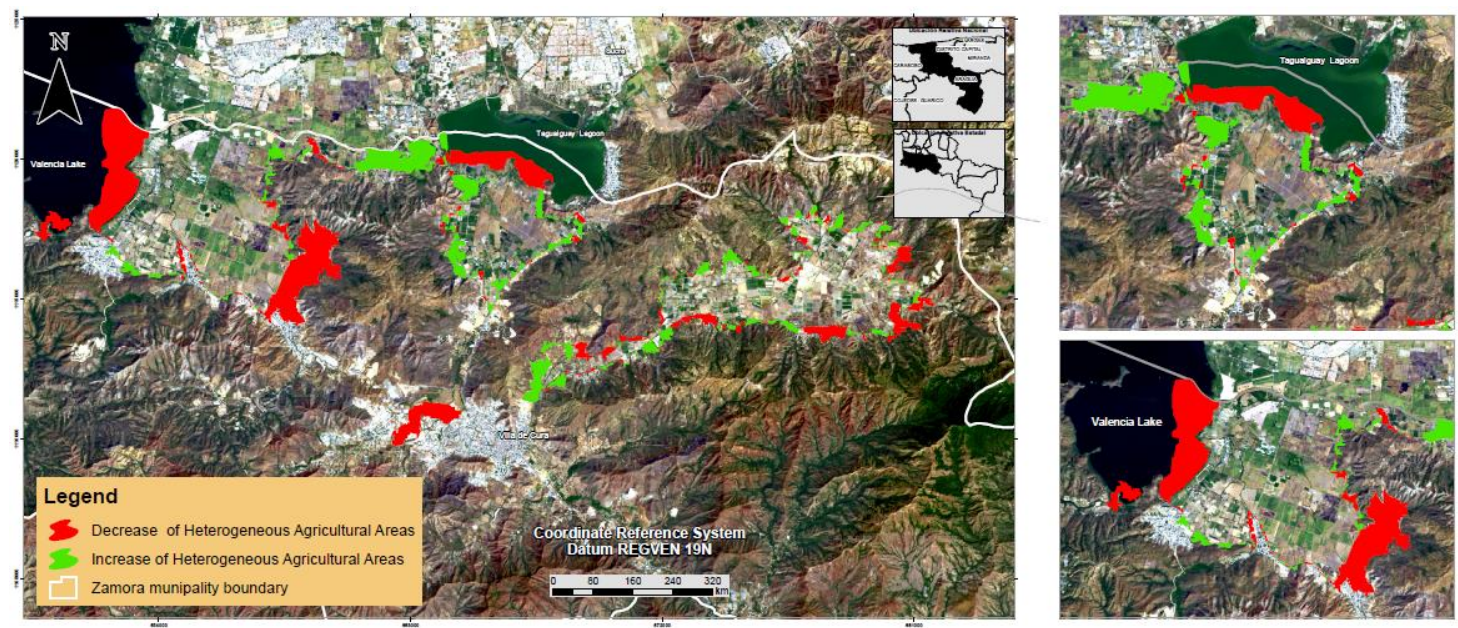

Figure 13. Increase and decrease of Heterogeneous agricultural areas between 1986 and 2016 


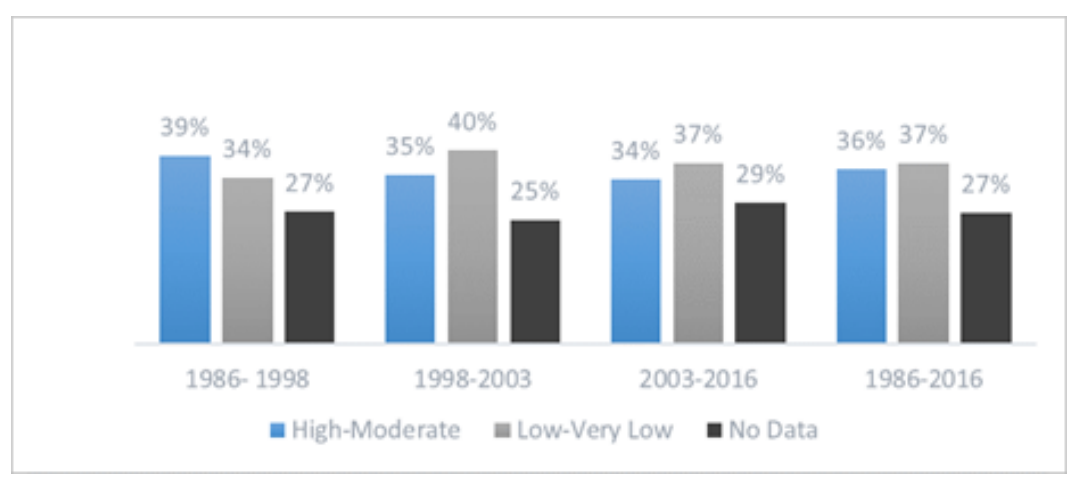

Figure 14. Potential for agricultural use affected by the increase of Heterogeneous agricultural areas between 1986 and 2016

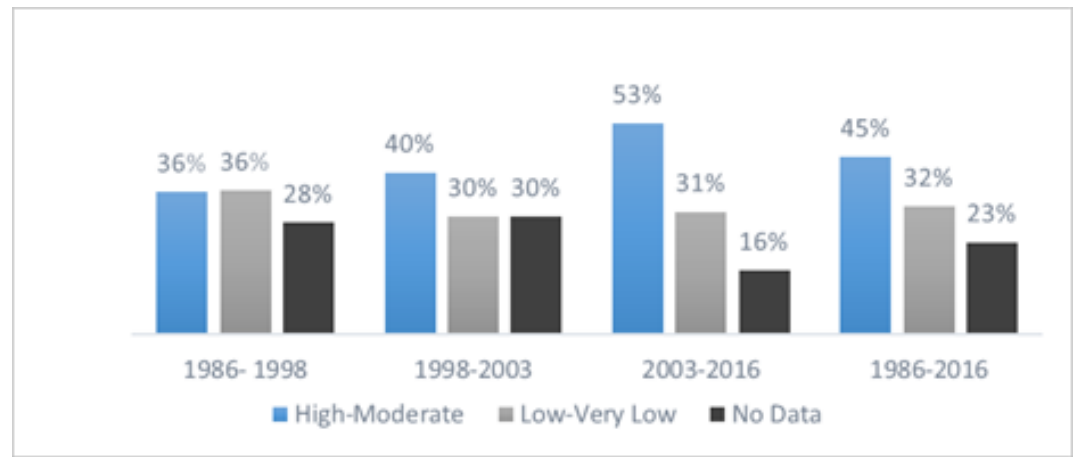

Figure 15. Potential for agricultural use affected by the increase of Heterogeneous agricultural areas between 1986 and 2016

\section{Discussion}

We classified Landsat images by using the object-based approach to describe LULC changes in Zamora municipality between 1986 and 2016. We $u$ d the image classification results in conjunction with SISDELAV data and feature extraction to determine the evolution of the Valencia Lake shoreline and identify areas in conflict with the potential for agricultural use. In general, we found a variable behavior of the LULC classes during this thirty-year study period. According to our results (Table 4), Inland waters and Urban fabric classes showed a steady increase during the study period. Open spaces with little or no vegetation, Mine and dump sites, and Industrial and commercial units raised between 1986 to 2003 and then dropped in 2016. Heterogeneous agricultural areas and Scrub and/or herbaceous vegetation associations experienced a downward trend in area with peaks and drops. Forest class showed a dramatic decrease from 1986 to 1998 and then a steep growth between 1998 and 2016. Previous studies have found similar results in areas and time-lapses overlapping with our area and period of study. From 1986 to 2001, in the Valencia Lake basin, Ormeño (2002) reported reductions in agricultural lands and increases in urban uses and the Valencia Lake. Inland waters, urban areas, and bare soils experienced increments while other categories such as Forests and agriculture areas showed decreases in Zamora, Liberator, José Angel Lamas and Sucre municipalities between 1986 and 2001 (Tejada, 2006).
We assessed the image accuracy through the unbiased accuracy assessment method and the CGLS-LC100 as a reference dataset. The overall accuracy was $69 \%$, which means that on average the chance a pixel will be correctly classified is $69 \%$. Our best user's accuracy was $84 \%$ (Inland waters) and the best producer's accuracy was $95.6 \%$ (Heterogeneous agricultural areas). On the other hand, the worst users' accuracy was $47.7 \%$ (Heterogeneous agricultural areas) and the worst producer's accuracy was $50.8 \%$ (Urban fabric) (Table 3). It has been reported overall accuracy over $80 \%$ when using object-based approach to classify L ndsat imagery (Oruc, et al., 2004, Kindu, et al., 2013, Estoque, et al., 2015, Poursanidis, et al., 2015). However, we would like to point out that our overall accuracy was slightly below $75-85 \%$ which is the acceptable range of this metric (Mubako, et al., 2018). This could stem from two issues: first, the difference between the spatial resolution of the reference data $(100 \mathrm{~m})$ and the classified data $(30 \mathrm{~m})$ could affect sampling results. When us ng medium to high-resolution imagery as reference data, we can only extract a small amount of the landscape variability because our pixels are small and therefore the area covered by the sample units are small too Congalton and Green, 2019), on the contrary, we extract a large amount of the landscape variability with low-resolution imagery because the sample units overlap more surface. In our case, it is possible that a sample unit containing a given class we classified using Landsat data, was identified as a more general or predominant class on CGLS-LC100 data due to differences in pixel size between both datasets. Second, we had to visually 
interpret Landsat image composites to extract urban and agricultural areas. Errors could therefore arise during the interpretation process due to the interpreter skills (Congalton and Green, 2019). Inaccurate visual interpretations could undermine user's and producer's accuracy of both Heterogeneous agricultural areas and Urban fabric categories respectively. More research is required on assessing object-based classification using images with different spatial resolutions in our study area. Also, it would be interesting to investigate whether is possible to achieve high overall accuracy combining Landsat and high-resolution images (Toure, et al., 2018) because object-based classification is mainly used to classify high-resolution imagery (Ma, et al, 2017).

Our results provide compelling evidence for long term increments of the Forest class, especially after 1998. This suggests a secondary succession process characterized by changes in plant communities whereby vegetation has been disturbed but the soil has not been removed (Gibson and Gibson, 2006). From Table 4, and Figures 7 and 8, we can infer that owing to a secondary succession, areas occupied by Scrub and/or herbaceous vegetation in 1986 changed into Forest in 2016. Understanding how forest areas are changing due to local patterns of succession can help planers to visualize how the landscape will change over the next years (Perman and Milder, 2004), especially in the Valencia Lake basin. In the same way, we found evidence that urban areas exhibited an upward trend during the study period. In the beginning, the urban growth overlaid land with low potential for agricultural use, then when engineering limitations constrained the urbanization, lands with high potential for agricultural use were affected (period 2003-2016) (Table 7). This finding about urban growth are explain by the fact that built-up areas in the Valencia Lake basin have been populated untidily around urban centers and towards unsuitable areas for urbanization (de La Rosa, 2009; Jaimes, 2011). These insights should alert urban planners in the region because as a result of urban sprawl, prime farmlands can be negatively affected, resulting in irreversible change of forest and agricultural lands into urban areas (Doygun, 2009). It is crucial to understand how urban expansion and agricultural land use interact because it allows to formulate land use planning polices and plans to balance the pressure of urban growth on farmlands (Jiang, et al., 2013). Although our findings were aligned with other author's claims about the relationship between urban growth and farmland, SISDELAV data only covered $61 \%$ of our study area (Table 7 ). Future works should, therefore, produce the missing data in order to account for the potential for agricultural use affected by the urban growth in the entire study area.

In this study, we determined the evolution of the Valencia Lake shoreline from 1986 to 2016 in Zamora municipality using the DEM of SISDELAV data and classification results of Landsat images. The overall results indicate that the lake spread out into 544 ha and its water level (elevation) rose $35 \mathrm{~m}$. The data confirms an upward trend of the lake level especially for the last study year (2016), and the claim of (Castillo and Jiménez, 2013) who stated that since 2010 the lake level has grown. These results build on existing evidence of a direct relationship between water importation and water level rising. From 1981 on, the lake level has increased as a direct consequence of water importation (Jaime, 2011) and probably as a consequence of changes in moisture availability (Curtis, et al., 1999). This knowledge has various implications in economic activities in the Valencia Lake basin. The rising of the lake level implies more flooded areas that impacts agricultural activities due to loss of high-quality farmlands, infrastructure for farming activities and perennials crops (Guevara, 2000), this situation is relevant to Zamora municipality because between 1986 and $2016,63 \%$ of the farmlands affected by the shoreline growth were lands with high potential for agricultural use (Table 6). It should be noted that Landsat images were valuables because they allowed us to obtain lake boundaries from which we extracted the shoreline for each year of study. On the other hand, we used a DEM with a spatial resolution $(10 \mathrm{~m})$ that constrained the accuracy of the calculated water level for each study year. A more detailed DEM should therefore be used in order to estimate more accurate lake levels.

\section{Conclusions}

Evaluating land use and land cover through multitemporal remote sensing allows identifying patterns of long-term changes. Due to the vast amount of historical Landsat data, we can classify images and extract features that are used to create a snapshot of a given time. Successive snapshots are then compared to gain insights into how LULC has evolved over time. Mutitemporal remote sensing capabilities have been used in this study to gain understanding of LULC changes and the Valencia Lake shoreline evolution over a thirty-year period in Zamora municipality. This kind of study is important because it is a source of data and information for conceiving informed plans for land using planning.

The results show that there was a notable reduction of the scrub and/or herbaceous vegetation associations and to a lesser degree the Heterogeneous agricultural areas. On the other hand, other classes experienced remarkable increments in area: Forest, and Urban fabric. These findings are important to understand that LULC dynamics in the study area are related to secondary succession processes favoring forest recovery, and urban sprawl disturbing prime farmlands.

An upward trend of the Valencia Lake shoreline was observed, and for the last two study years (2003-2016) more than $50 \%$ of this raising occurred. This trend elicited conflicts with the potential agricultural land use. Lands with high potential for crop yields were affected by the lake shoreline increment. At the beginning the affectation was low and on soils with a high water table, then, in the period 2003-2016, the affected area was more extensive and mainly on well-drained soils with high potential agricultural land use.

In the image classification carried out by the objectbased approach, despite its moderate overall accuracy, 
built-up areas and vegetated covers were satisfactorily extracted. Notwithstanding the accuracy outputs, it is the first time this approach was applied in the study area to classify images intended for LULC studies. Also, this study does suggest that in the absence of classification rules based on shape, texture, and contextual information of the images, it is possible to separate objects through vegetation indexes and thematic layers like we did in this study.

In future studies, it is advisable to use high-spatialresolution images in order to improve image classification accuracy. High-resolution data could be very useful to separate objects in built-up areas wherein mid-resolution images tend to be more prone to generate errors. Therefore, high-spatial-resolution images in conjunction with mid-resolution images can be used to determine whether the object-based classification or the pixel-based classification is more suitable to conduct studies of LULC changes in our study area and its surroundings.

\section{Acknowledgments}

The author is sincerely grateful to the editors as well as the anonymous reviewers for their valuable suggestions and

comments that helped me improve this paper significantly.

\section{Appendix A. Supplementary material}

Supplementary data associated with this article can be found, in the online version, at doi:10.5281/zenodo.3978372

\section{References}

Berberoglu, S., Akin, A. (2009). Assessing different remote sensing techniques to detect land use/cover changes in the eastern Mediterranean. International Journal of Applied Earth Observation and Geoformation, 11, 46-53.

Burak, S., Doğan, E., Gazioğlu, C. (2004). Impact of urbanization and tourism on coastal environment, Ocean Coast Manag., 47, 15-527, 10.1016/j.ocecoaman.2004.07.007.

Buchhorn, M., Smets, B., Bertels, L., Lesiv, M., Tsendbazar, N. E., Herold, M., Fritz, S. (2019). Copernicus Global Land Service: Land Cover 100m: epoch 2015: Globe. Dataset of the global component of the Copernicus Land Monitoring Service 2019. DOI 10.5281/zenodo.3243509.

Campbell, J.B., Wynne, R.H. (2011). Introduction to Remote Sensing. New York: The Guilford Pres.

Chuvieco , E. (1995). Fundamentals of Remote Sensing Madrid: Ediciones Rialp S.A.

Fundacite (1999). A proposal for sustainable tourist use of the Valencia Lake Basin (Propuesta de uso turístico sostenible de la Cuenca del Lago de Valencia).

Gazioğlu, C., Yücel, Z. Y., Burak, S. Z., Okus, E., \& Alpar, B. (1997). Coastline changes and inadequate management between Kilyos and Karaburun shoreline. Turkish Journal of Marine Sciences, 3(2), $111-122$.

Giri, C. (2012). Brief Overview of Remote sensing of Land Cover. In: Giri, C. (Eds.), Remote Sensing of Land Use and Land Cover: Principles and Applications (3-12), New York, USA: Taylor \& Francis Group.

ICIMOD (2015). Land cover mapping using satellite data.

Instituto de Hidrología, Meteorología y Estudios Ambientales, Instituto Geográfico Agustín Codazzi, Corporación Autónoma Regional del Río Grande de la Magdalena. (2008). Land Cover Map of the Magdalena-Cauca Basin: CORINE Land Cover Methodology adapted to Colombia, 1:100000 Scale (Mapa de Cobertura de la Tierra Cuenca Magdalena Cauca: Metodología CORINE Land Cover adaptada para Colombia escala 1:100.000).

Islam K, Jashimuddin M, Nath B, Nath TK (2016) Quantitative Assessment of Land Cover Change Using Landsat Time Series Data: Case of Chunati Wildlife Sanctuary (CWS), Bangladesh. International Journal of Environment and Geoinformatics 3(2): 45-55.

Jaimes, E. (2011). Solutions to Environmental Problems of Valencia Lake (Soluciones a la Problemática Ambiental del Lago de Valencia).

Kaya, Ş., Çelik, B., Gazioğlu, C., Alganc1, U. \& Şeker, DZ. (2017). Assessment of the Relationship between Land Cover and Land Surface Temperatures Utilizing Remotely Sensed Data: A Case Study of Silivri, 19th MESAEP Symposium on Environmental and Health Inequity, Rome, ITALY, 3-6 Dec 2017.

Kaya, S., Gazioğlu, C., Sertel, E., Şeker, D.Z., and Alganc1, U., (2015). Rapid determination of land use/cover changes using data fusion. The 36th Asian Conference on Remote Sensing "Fostering Resilient Growth in Asia", Metro Manila, Filipinler, 19-23 October 2015.

Mallinis, G., Georgiadis C. (2019). Editorial of Special Issue "Remote Sensing for Land Cover/Land Use Mapping at Local and Regional Scales". MDPI Remote Sens, 11(19), 2202.

Mohammad1, M , Hosseinal1, F . (2019). Assessment and Comparison the Location of Six Universities in Tehran City Using GIS and Multi Criteria Decision Making Methods, International Journal of Environment and Geoinformatics, 6(1), 143-147. Doi.10.30897/ijegeo.551753.

Mubako, S., Belhaj, O., Heyman, J., Hargrove, W., Reyes, C. (2018). Monitoring of Land Use/LandCover Changes in the Arid Transboundary Middle Rio Grande Basin Using Remote Sensing. MDPI Remote Sens, 10(12), 2005.

Navulur, K. (2007). Multispectral image analysis using the object-oriented paradigm. Boca Raton: CRC Press Taylor \& Francis Group.

NCCOS. (2017). Sampling Design Tool for ArcGIS.

Ngan Lam, N. (2008). Methodologies for Mapping Land Cover/Land Use and its Change. In: Liang, S. (Eds.), Advances in Land Remote: System, Modeling, 
Inversion and Application (341-367), Springer Science+Business Media B.V.

Olofsson, P., Foody, G.M., Herold, M., Stehman, S.V., Woodcock, C.E., Wulder, M.A. (2013). Making better use of accuracy data in land change studies: Estimating accuracy and area and quantifying uncertainty using stratified estimation, Remote Sensing of Environment, 129, 122-131, DOI: 10.1016/j.rse.2012.10.031.

Ormeño, M. (2002). Urban expansion on prime agricultural lands at the Valencia Lake depression (Expansión del uso sobre las tierras agrícolas de primera calidad en la depresión del Lago de Valencia: evolución y tendencias) (MSc thesis). Central University of Venezuela, Caracas, Venezuela.

Patil, M.B., Desai, C.G., Umrikar, B.N. (2012). Image classification tool for land use / land cover analysis: a comparative study of maximum likelihood and minimum distance method. International Journal of Geology, Earth and Environmental Sciences, 2(3), 189-196.

Pontes, A. (2013). Spatial and multitemporal analysis of land use and land Cover in Casa Nova municipality, Bahia, period 1996-2011 (Análise multitemporal e espacial do uso e cobertura das terras no município de Casa Nova, Bahia, no período de 1996 a 2011) (MSc thesis). State University Feira de Santana, Feira de Santana, Brazil.

Rodríguez, A.F. (2011). A methodology to identify land use changes using object-oriented principles, study case: Villavicencio's foothills, Meta state (Metodología para detectar cambios en el uso de la tierra utilizando los principios de la clasificación orientada a objetos, estudio de caso piedemonte de Villavicencio, Meta).

Rogan, J., DongMe, C. (2004). Remote sensing technology for mapping and monitoring land-cover and land-use change. Progress in Planning, 61, 301325.

Tejada, A. (2006). Multitemporal analysis of land use changes through Landsat images. Study case: Zamora, Libertador, José Ángel Lamas and Sucre municipalities Aragua state (Análisis multitemporal de cambio de uso de la tierra mediante el empleo de imágenes del satélite Landsat. Caso de estudio: municipios Zamora, Libertador, José Ángel Lamas y Sucre del estado Aragua) (PGDip thesis). Central University of Venezuela, Caracas, Venezuela.

The Encyclopedia of Earth (2010). Land-use and landcover change.

Toure, S.; Stow, D.; Shih, H.; Weeks, J.; Lopez-Carr, D. (2018). Land cover and land use change analysis using multi-spatial resolution data and object-based image analysis. Remote Sensing of Environment, 210, 259-268.

USGS. (2015). What are the best Landsat spectral bands for use in my research?
Wikipedia (2014). Zamora Municipality (Aragua State) (Municipio Zamora (Aragua)

Wikipedia (2017). Endorheic basin.

Xiaoxiaa, S., Jixiana, Z., Zhengjuna, L. (2004). An Object-Oriented Classification Method on High Resolution Satellite Data. 